and its relative concentration with significative differences in the acquired spectra, to obtained the so called specific Phe NIR fingerprint of the sample These observation open the exciting possibility to design a chemiometric model to assay the amount of Phe in DBS without elution and the expensive chromatographic procedures.

\section{GP16 EFFECT OF DROPLET SIZE ON AEROSOL DELIVERY DURING SIMULATED NEONATAL MECHANICAL VENTILATION}

Gavin Bennett*, Mary Joyce, Elena Fernández Fernández, Ronan MacLoughlin. Aerogen, Galway, Ireland

\subsection{6/archdischild-2019-epa.83}

Introduction Invasive mechanical ventilation is a mainstay in neonatal intensive care and co-administration of aerosolised therapeutics is commonly prescribed. Considering their rapid breathing rate, low tidal volumes, small airways and interfaces, neonates present unique challenges for aerosol therapy. The objective of this study was to assess the effect of droplet size on aerosol delivery during simulated ventilation of a neonate.

Methods Simulated neonatal mechanical ventilation assessed the lung dose beyond the endotracheal tube (ETT) across two potential nebuliser placement positions within the circuit; at the dry side of the humidifier and between the Wye and ETT. $2 \mathrm{ml}$ of $2 \mathrm{mg} / \mathrm{ml}$ salbutamol was nebulised using two vibrating mesh nebulisers (Aerogen Solo, Aerogen, Ireland) of varying droplet size $(2.76 \mu \mathrm{m}$ and $4.30 \mu \mathrm{m}$ respectively). A vibrating mesh nebuliser was chosen as it does not add flow or pressure to the ventilator circuit. A neonatal ventilator (VN500, Dräger, Germany) ( $\mathrm{V}_{\mathrm{t}} 10 \mathrm{~mL}$, 60BPM, I:E ratio 1:2) in combination with a $2.5 \mathrm{~mm}$ ETT and humidified circuit was used. Lung dose was quantified after capturing aerosol on an absolute filter (RespirGard II 303, Baxter, Ireland) positioned between the ETT and test lung. The mass of drug eluted was determined using UV Spectrophotometry at $276 \mathrm{~nm}$. Results were expressed as a percentage of the nominal dose placed in the nebuliser medication cup.

Results

Abstract GP16 Table 1 Lung dose (\%) using two nebulisers of varying droplet size, at two positions within the circuit. P-values are included to indicate significance.

\begin{tabular}{|c|c|c|c|}
\hline \multirow[t]{2}{*}{ Nebuliser position } & Lung dose (\%) & Lung dose (\%) & P-value \\
\hline & $2.76 \mu \mathrm{m}$ & $4.30 \mu \mathrm{m}$ & \\
\hline Dry side of the humidifier & $1.93 \pm 0.20$ & $1.39 \pm 0.11$ & 0.02 \\
\hline Between Wye and ETT & $3.88 \pm 1.24$ & $2.75 \pm 0.77$ & 0.25 \\
\hline
\end{tabular}

Discussion Increasing droplet size was associated with a significantly reduced lung dose when the nebuliser was positioned at the dry side of the humidifier ( $p$-value $=0.02$ ). Increasing droplet size was associated with a reduced lung dose when the nebuliser was placed between the Wye and ETT. However, this difference was not found to be statistically significant ( $p$ value $=0.25$ ). In conclusion, these findings demonstrate that droplet size affects aerosol delivery during neonatal mechanical ventilation.

\section{GP17 \\ DISTRIBUTION OF NON-FUNCTIONAL ALLELE OF CYP2D6 GENE (RS1065852) AMONG BURYAT ADOLESCENTS}

Tatyana Bairova, Ksenia levleva, Lyudmila Bodonova, Lyubov Rychkova*. Scientific Centre for Family Health and Human Reproduction Problems, Irkutsk, Russian Federation

\subsection{6/archdischild-2019-epa.84}

Introduction Individual reaction to medicine is determined by genetic factors. The CYP2D6 gene is involved in the metabolism of $20-25 \%$ of medication. The carriage of CYP2D $6 * 10$ determines the synthesis of a defective protein with a reduced activity of the CYP2D6 isoenzyme, which determines the difference in interindividual medicine variability and an increased risk of undesirable drug reactions. Distribution of CYP2D6*10 varies in different races and ethnic groups.

Methods In 151 Buryat adolescents, DNA was isolated from whole venous blood, the allelic composition was determined by the CYP2D6*10 gene polymorphism (rs1065852). The average age of the subjects was $16.02 \pm 2.05$ years. Buryats belong to the indigenous people living on the Asian part of Russia. They belong to the Mongoloid race and are part of the small North Asian race. When forming the samples, ethnicity was taken into account in at least three generations.

Result Identified carriers of two genotypes rs1065852 CYP2D6*10: SS (70.19\%) and CT (29.81\%). The prevalence of functional C-allele was 85.1\%; non-functional T-allele $14.9 \%$. When comparing the prevalence of non-functional Tallele rs1065852 CYP2D6*10 with the same indicator in other populations of the world, significant differences with the Mongols (T-allele frequency $55.0 \%, \mathrm{p}<0.001$ ), Japanese (Tallele frequency $44.7 \%, \mathrm{p}<0.001)$, Filipinos $(5.4 \%, \mathrm{p}<0.001)$, Bedouins (4.7\%, $\mathrm{p}=0.0146)$, representatives of the Mbuti tribe $(0 \%, p=0.0366)$. No significant differences in the prevalence of non-functional T-allele rs1065852 CYP2D6*10 with Caucasions (12.5-22.5\%), Yakuts (17.5\%), Japanese (15.0\%), African Americans (9.9-13\%) and some residents of the Middle East (7.9-25.9\%).

Conclusions The presence of significant differences in distribution of non-functional T-allele CYP2D6*10 (rs1065852) in the Buryat population was shown in comparison with some populations of the Mongoloid and Negroid races.

\section{GP18 NEONATES BORN TO RHESUS POSITIVE WOMEN WITH PERINATALLY-DETECTED RED CELL ANTIBODIES: A CASE SERIES}

${ }^{1}$ Lucy E Geraghty*, ${ }^{2}$ Joan Fitzgerald, ${ }^{2}$ Donal Noonan. 'Department of Neonatology, The National Maternity Hospital, Holles Street, Dublin 2, Ireland; '2Department of Blood Transfusion and Haematology, The National Maternity Hospital, Holles Street, Dublin 2, Ireland

\subsection{6/archdischild-2019-epa.85}

Background Haemolytic Disease of the Fetus \& Newborn (HDFN) results from maternal IgG red cell allo-antibodies crossing the placenta $\&$ binding to their corresponding antigen on red cells in the fetal circulation. Immune haemolysis can cause varying degrees of anaemia \& unconjugated hyperbilirubinaemia in the fetus $\&$ neonate.

At present, all women have bloods drawn for group \& antibody screen at booking. For expectant mother who test $\mathrm{RhD}$ positive, repeat antibody screening is not carried out in the absence of antibodies at booking. 